\title{
Paternity and relatedness of American black bears recolonizing a desert montane island
}

\author{
Dave P. Onorato, Eric C. Hellgren, Ronald A. Van Den Bussche, and \\ J. Raymond Skiles, Jr.
}

\begin{abstract}
American black bears (Ursus americanus (Pallas, 1780)) are characterized by female philopatry and malebiased dispersal, with predictable consequences for genetic structure of populations. We studied a recolonizing population of black bears on a desert montane island to test genetic-based predictions of bear social behavior. We assessed genetic paternity and relatedness among bears within Big Bend National Park, Texas, from 1998 to 2001 via maternally and biparentally inherited markers and field observations. Data from seven microsatellite loci permitted us to assign paternity for 7 of 12 cubs, and multiple paternity was revealed in one litter. Levels of relatedness in the Park were comparable to those found in a nearby large population in Coahuila, Mexico. Adult female bears in the Park were more closely related to each other than males were to each other. Microsatellite data were consistent with previous analyses of mtDNA sequences that indicated bears in the Mexico-Texas metapopulation exhibit male-biased dispersal. Demographic and genetic data provided a pedigree for 23 of 31 sampled bears and depicted the matriarchal structure of this recently recolonized population. Although females in this insular population are closely related to each other, as predicted by characteristics of ursine social ecology, incoming dispersal by unrelated males results in periodic supplementation of genetic variation.
\end{abstract}

Résumé : Les ours noirs américains, Ursus americanus (Pallas, 1780), se caractérisent par une philopatrie des femelles et une dispersion faite surtout par les mâles, ce qui a des conséquences prévisibles sur la structure génétique des populations. Nous avons étudié une population d'ours noirs qui est en train de se rétablir sur une montagne isolée en région désertique afin de vérifier des prédictions sur leur comportement social basées sur la génétique. Nous avons évalué la paternité génétique et le degré de parenté des ours du parc national de Big Bend, Texas, de 1998 à 2001, au moyen de marqueurs hérités de la mère ou des deux parents et par des observations de terrain. Les données sur sept locus microsatellites nous ont permis d'attribuer la paternité de 7 de 12 oursons et d'identifier une paternité multiple dans une portée. Le degré de parenté dans le parc est semblable à celui que l'on trouve dans la grande population voisine de Coahuila, Mexique. Les ourses adultes sont plus proches parentes les unes des autres que ne le sont les mâles. Les données sur les locus microsatellites sont en accord avec des analyses antérieures des séquences d'ADNmt qui indiquent que les ours de la métapopulation Mexique-Texas ont une dispersion qui est surtout l'apanage des mâles. Des données démographiques et génétiques ont permis de dresser le pedigree de 23 des 31 ours échantillonnés et la description de la structure matriarcale de cette population colonisatrice récente. Bien que les femelles de cette population isolée soient fortement apparentées les unes aux autres, tel que le prédisent les caractéristiques de l'écologie sociale des ursinés, l'arrivée par dispersion de mâles non apparentés amène un accroissement périodique de la variation génétique.

[Traduit par la Rédaction]

\section{Introduction}

Gaining an understanding of the social ecology of mammals has become increasingly important from both management and conservation perspectives. For example, sociological data indicating that a species typically displays male-biased dispersal patterns can have considerable ramifications for the management initiatives proposed for the spe- cies (see White et al. 2000). Decisions that utilize these data should have a positive effect on conservation attempts. Researchers have recently begun to incorporate data from both field observations and molecular markers to assess aspects of social organization in mammals. Highly polymorphic genetic markers enable predictions concerning mammalian sociality via analyses of relatedness (Blouin et al. 1996; Cronin et al. 1999; Lunn et al. 2000), immigration (Rannala

Received 21 February 2004. Accepted 8 July 2004. Published on the NRC Research Press Web site at http://cjz.nrc.ca on 7 October 2004.

D.P. Onorato, ${ }^{1,2}$ E.C. Hellgren, and R.A. Van Den Bussche. Department of Zoology and Oklahoma Cooperative Fish and Wildlife Research Unit, 430 LSW, Oklahoma State University, Stillwater, OK 74078, USA.

J.R. Skiles, Jr. Science and Resource Management Unit, Big Bend National Park, TX 79834, USA.

${ }^{1}$ Corresponding author (e-mail: Onorato@uidaho.edu).

${ }^{2}$ Present address: Department of Fish and Wildlife Resources, University of Idaho, P.O. Box 441136, Moscow, ID 83844-1136, USA. 
and Mountain 1997), dispersal (Girman et al. 1997; Gompper et al. 1998; Banks et al. 2002), paternity (Clapham and Palsboll 1997; Constable et al. 2001), and genetic structure (Paetkau et al. 1995; Waits et al. 2000) of animal populations.

Predictably, most sociality studies of large carnivores have focused on the few gregarious taxa. These include lions (Panthera leo L., 1758) (Schaller 1972; Packer et al. 1991), white-nosed coati (Nasua narica L., 1766) (Gompper et al. 1998), spotted hyena (Crocuta crocuta Erxleben, 1777) (Engh et al. 2000), and, most recently, kinkajous (Potos flavus Schreber, 1774) (Kays et al. 2000). Some of these studies have been instrumental in the discovery of sociological characteristics of species, such as group hunting and communal rearing of offspring in lions (Packer et al. 1991). Results from Kays et al. (2000) suggested that female dispersal is more prevalent than male dispersal in kinkajou social groups, an unexpected role reversal in mammals.

Assessments of sociological characteristics of nongregarious species of carnivores that have utilized both field and molecular data are less common (Craighead et al. 1995; Lunn et al. 2000). Nevertheless, such studies can be instrumental in the conservation of rare and threatened species because knowledge of dispersal patterns, relatedness groupings, and kinship is instrumental in recovery plans. This is especially true for large members of the order Carnivora. These species are typically characterized by small populations and low reproductive rates and are vulnerable to habitat loss and stochastic events imposed by these life-history characters.

The American black bear (Ursus americanus (Pallas, 1780)) has been characterized as having male-biased dispersal and female philopatry (Rogers 1987b; Schwartz and Franzmann 1992). Long-term observations of a population in Minnesota revealed a land-tenure system among females, with residents and their female offspring occupying adjacent home ranges but male offspring dispersing from the area (Rogers 1987b). These observations predict close associations between genetic relatedness of females and spatial organization of females. A previous test of this prediction showed no relationship between spatial organization and average genetic relatedness measured by DNA fingerprinting (Schenk et al. 1998). Schenk et al. (1998) proposed possible reasons for the lack of support for the predicted associations, including more frequent female dispersal and higher density in their study population than in that of Rogers (1987b).

We have previously described a naturally recolonizing metapopulation of black bears in the island mountain ranges of the Chihuahuan Desert of western Texas (Onorato and Hellgren 2001). mtDNA analyses have demonstrated that this metapopulation is structured by limited female dispersal (Onorato et al. 2004), as predicted from the female philopatry of black bears. Given the recent initiation of the recolonization, we believe that analyses of microsatellite data from a single insular population in this system will supplement the mtDNA data for a direct test of the Rogers (1987b) paradigm of bear social structure. Study of the population of bears in Big Bend National Park (Big Bend NP) enables us to avoid the behavioral issues of density-dependent movement and high rates of female dispersal possibly encountered by Schenk et al. (1998).
Our specific objectives were to describe paternity and relatedness for an insular population of American black bears located in Big Bend NP. We tested several theoretical predictions of Rogers (1987b), including the prevalence of malebiased dispersal, female philopatry, and a female land-tenure system in black bears. We predicted that overall relatedness of black bears in Big Bend NP would be equivalent to the level of relatedness found in source populations in Mexico because of previously noted male-biased dispersal patterns in this ecosystem. Intrasexual relatedness in Big Bend NP should be higher in females than in males because of patterns of haplotype distribution noted in previously analyzed mtDNA sequence data (Onorato et al. 2004) and female philopatry in bears (Rogers 1987b; McLellan and Hovey 2001). Additionally, we expected that paternity assignments would include adult males that are highly related to reproductive females because of the isolated nature of this population. Lastly, we predicted that recolonization of Big Bend NP was initiated by the dispersal and colonization of a single matriarch female (as hypothesized by Onorato and Hellgren 2001). If the aforementioned patterns of female philopatry apply, the female segment of the population would be primarily descendents of that matriarch. Data on relatedness of known mother-offspring dyads and a nearly complete census of the population (Onorato et al. 2003) permitted development of a pedigree for a majority of the population.

\section{Methods}

\section{Study area}

Fieldwork and laboratory analyses concentrated on the population of black bears located in Big Bend NP, Texas (Fig. 1). Individuals were captured using barrel traps typically located in the higher elevations of the Chisos Mountains. Bears were immobilized using Telazol ${ }^{\circledR}$ (Fort Dodge Laboratories Inc., Fort Dodge, Iowa) at a concentration of $5.5 \mathrm{mg} / \mathrm{kg}$. At the time of initial capture, each bear was given a unique identification number by implanting a passive integrated transponder tag to provide a permanent and unequivocal marker. The first upper premolar of all bears $>1$ year old was extracted using dental elevator and extractor tools. Age was estimated via cementum annuli analysis (Willey 1974) by a commercial laboratory (Matson's Laboratory, Milltown, Montana).

Tissue samples (blood or ear tissue) were collected from 31 bears from 1998 to 2000. An additional sample from a large adult male (muscle tissue) found dead in a remote canyon within the Park in 1994 was included in this study. For some analyses, these 32 samples were compared with samples from populations of bears in western Texas and northern Mexico (Fig. 1). All samples were analyzed in previous work by the authors (Onorato et al. 2004) and were collected during several concurrent black bear studies in southwestern North America (McKinney and Pittman 2000; Doan-Crider 2003).

\section{DNA isolation and microsatellite PCR}

Samples were stored either frozen $\left(-20{ }^{\circ} \mathrm{C}\right)$ or in lysis buffer during transport to the laboratory, where total geno- 
Fig. 1. Locations of sampling areas within northern Mexico and western Texas. Tissue samples collected from American black bears (Ursus americanus) in the Sierra del Carmen $(N=5$; Carmens), the Black Gap Wildlife Management Area $(N=12$; Black Gap), and the Trans-Pecos region $(N=5$; Trans-Pecos) were used in several analyses including the neighbor-joining tree. The population of bears in the Serranías del Burro (Burros) is theorized to be a source population of black bears for former range located in western Texas, and samples from this population were previously analyzed (Onorato et al. 2004; D.P. Onorato, unpublished data). Additionally, the present range of American black bears in southwestern North America is depicted by the shaded areas (derived from Pelton et al. 1999). The map is centered on Big Bend National Park, Texas (UTM 13R 0668599E $3233137 \mathrm{~N})$.

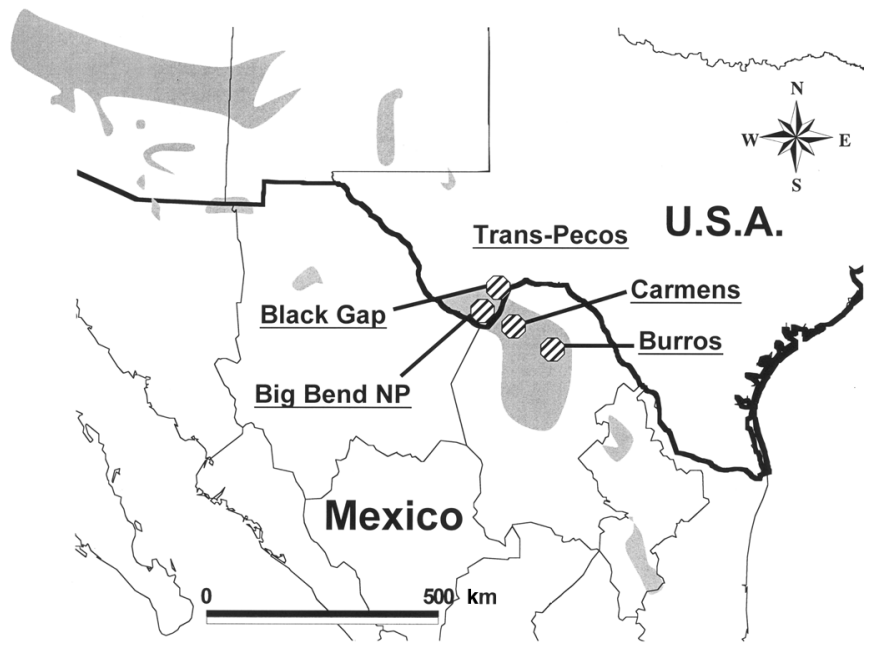

mic DNA was extracted using phenol extraction (Maniatis et al. 1989). Seven $(\mathrm{GT})_{n}$ microsatellite loci were initially amplified using the polymerase chain reaction (PCR) and primers described in Paetkau et al. (1998). Six loci (G1D, G10B, G10C, G10H, G10J, G10P) were cloned from a small-insert American black bear genomic library (Paetkau and Strobeck 1994; Paetkau et al. 1995), whereas the seventh locus, CXX20, was derived from a domestic dog (Canis familiaris L., 1758) genomic library (Ostrander et al. 1993). One primer of each pair was synthesized with a fluorescent dye (FAM, HEX, or TET) to permit detection and sizing of microsatellite repeats on an ABI Prism ${ }^{\circledR} 377$ DNA Sequencer (Perkin-Elmer Applied Biosystems Inc., Foster City, California).

Amplifications were performed in $15-\mu \mathrm{L}$ reactions using 50-200 ng of DNA, $0.17 \mu \mathrm{mol} / \mathrm{L}$ of each primer, $9 \mu \mathrm{L}$ of True Allele PCR Premix (Perkin-Elmer Applied Biosystems Inc.), and $3.8 \mu \mathrm{L}$ of double-deionized water. Amplifications for all samples collected in Big Bend NP and the Black Gap Wildlife Management Area (Black Gap WMA) were replicated at least twice. The following thermal profile was used during amplification: $12 \mathrm{~min}$ at $95{ }^{\circ} \mathrm{C} ; 10$ cycles of $15 \mathrm{~s}$ at $94{ }^{\circ} \mathrm{C}, 1 \mathrm{~min}$ at $49-55^{\circ} \mathrm{C}$ (annealing temperatures were specific for different loci), and $30 \mathrm{~s}$ at $72{ }^{\circ} \mathrm{C} ; 25$ cycles of $15 \mathrm{~s}$ at $89{ }^{\circ} \mathrm{C}, 1 \mathrm{~min}$ at $55^{\circ} \mathrm{C}$, and $30 \mathrm{~s}$ at $72{ }^{\circ} \mathrm{C}$; and $30 \mathrm{~min}$ at $72{ }^{\circ} \mathrm{C}$. PCR products were diluted and combined based on size, fluorescent dye, and yield. One microlitre of PCR dilution was added to $3 \mu \mathrm{L}$ of loading buffer containing $0.5 \mu \mathrm{L}$ of GeneScan ${ }^{\circledR}-400 \mathrm{HD}$ ROX size standard, $0.5 \mu \mathrm{L}$ of loading dye, and $2.5 \mu \mathrm{L}$ of formamide. This mixture was denatured at $95{ }^{\circ} \mathrm{C}$ for $5 \mathrm{~min}$ and loaded on a $6 \%$ Long Ranger ${ }^{\circledR}$ acrylamide gel (Cambrex Corp., East Rutherford, New Jersey) and the resulting data were analyzed using GeneScan ${ }^{\circledR}$ software version 3.1.2 and Genotyper ${ }^{\circledR}$ software version 2.5.

\section{Data analyses}

Assessment of observed $\left(H_{\mathrm{o}}\right)$ and expected $\left(H_{\mathrm{e}}\right)$ heterozygosity, deviations from Hardy-Weinberg equilibrium (HWE, Guo and Thompson 1992), determination of polymorphic information content (PIC), and exclusion probabilities were calculated using CERVUS (Marshall et al. 1998). Tests involving multiple comparisons in CERVUS were corrected for the increased likelihood of making a type I error using the sequential Bonferroni adjustment.

We used genotypic data collected from all cubs with known mothers (verified via den workup or capture) to estimate paternity based on the exclusion process of Mendelian genetics. When paternity could not be determined unambiguously using genetic exclusion, likelihood-based paternity analyses were utilized. Likelihood-based paternity assessment incorporates probability of mutation events and genotyping error in assessing paternity that can be quantified statistically. $\mathrm{Pa}$ ternity using likelihood ratios was calculated using CERVUS (Marshall et al. 1998). CERVUS calculates a $\triangle$ LOD score, which is defined as the difference in the log-likelihood ratio at each locus (LOD) between the most likely and second most likely candidate parents. The LOD for each candidate father is calculated using genotypes of the candidate father, offspring, and known parent (the mother in our study).

The statistical significance of $\triangle \mathrm{LOD}$ is determined via a simulation that incorporates incomplete sampling, genotyping error rates, number of candidate parents, and proportion of missing genotypes (Marshall et al. 1998). For our analyses, we estimated that we sampled $75 \%(n=7)$ of the candidate males in Big Bend NP and the nearby Black Gap WMA that were categorized as breeders ( $>3$ years of age) when corresponding cubs were born. Adult males from the Black Gap WMA were included for two reasons: proximity of this population to that of Big Bend NP, and the fact that several of the adult males in this population had been relocated to this area and were therefore excellent candidates for extensive movements. We are confident that we captured $75 \%$ of adult males in Big Bend NP (three of four observed during field seasons) and that McKinney and Pittman (2000) captured $>75 \%$ of the adult males in the Black Gap WMA.

Marshall et al. (1998) noted that assuming genotypic data to be free of errors can lead to an overestimation of confidence levels and therefore recommended estimating error rates via allelic mismatches between mothers and known offspring. Using this criteria, our resulting error rate was $1 \%$. The percentage of missing data for genotypes $(1.6 \%)$ was determined by calculating the proportion of loci that did not amplify for all bear tissue samples collected in Big Bend NP and the Black Gap WMA. Confidence levels for $\triangle \mathrm{LOD}$ were set at $80 \%$ and $95 \%$.

We calculated an index of relatedness $(r)$ using the software Relatedness 5.0.8 (Queller and Goodnight 1989) to estimate relationships among individuals within Big Bend NP. 
Table 1. Diversity characteristics of seven microsatellite loci amplified for 32 American black bear (Ursus americanus) tissue samples collected in Big Bend National Park, Texas, between 1994 and 2000.

\begin{tabular}{lllllllll}
\hline Locus & $k$ & No. of bears genotyped & $H_{\mathrm{o}}$ & $H_{\mathrm{e}}$ & PIC & Excl1 & Excl2 & HWE \\
\hline G1D & 5 & 32 & 0.563 & 0.712 & 0.662 & 0.294 & 0.474 \\
G10B & 5 & 32 & 0.719 & 0.699 & 0.643 & 0.277 & 0.452 & NS \\
G10C & 4 & 32 & 0.750 & 0.737 & 0.675 & 0.301 & 0.474 \\
G10H & 6 & 30 & 0.500 & 0.443 & 0.407 & 0.102 & 0.249 & NS \\
G10J & 5 & 30 & 0.767 & 0.694 & 0.630 & 0.262 & 0.430 & NS \\
G10P & 6 & 32 & 0.844 & 0.759 & 0.713 & 0.352 & 0.534 \\
CXX20 & 6 & 32 & 0.844 & 0.793 & 0.746 & 0.392 & 0.571 \\
Mean & 5.3 & & 0.712 & 0.691 & 0.639 & & NS \\
\hline
\end{tabular}

Note: $k$, number of alleles per locus; Excl1 and Excl2, exclusionary power of each locus for parentage analyses when no parents are known (Excl1) or when one parent is known (Excl2); other abbreviations are defined in the text. Significance of HWE deviations was corrected using the sequential Bonferroni method for multiple comparisons; NS, nonsignificant.

Additionally, we assessed overall levels of relatedness within Big Bend NP, the Black Gap WMA, the Sierra del Carmen, and the Trans-Pecos region, as well as within a large population of black bears in the Serranías del Burro (Burros, Fig. 1). The index $r$ uses data on population allele frequency to assess the proportion of alleles in a population that are identical by descent between two individuals. The value of $r$ can range from -1 to 1 , with negative values indicating unrelated dyads and positive values indicating some degree of relatedness. In calculating $r$, bias is corrected for small sample size in each population by recalculating population mean frequencies after omitting the population under consideration (Queller and Goodnight 1989). The index was weighted equally among individuals and standard errors of $r$ were estimated by jackknifing over all seven loci (Queller and Goodnight 1989).

Pairwise comparisons of mean $r$ values were made between mothers and known offspring and between potential fathers (as assessed via paternity analyses) and offspring in Big Bend NP to determine whether levels of relatedness were similar to expected values for parent-offspring relationships $(r=0.50)$. Average pairwise estimates of $r$ for adult (females $\geq 4$ years old and males $\geq 3$ years old) malefemale, female-female, and male-male dyads were calculated for Big Bend NP bears. A nonparametric two-group randomization test (Sokal and Rohlf 1995) was used to test the assumption that mean pairwise $r$ values within sex did not differ from randomly selected $r$ values across sex. Observed $r$ values were permutated among groupings 5000 times to compare means obtained via observed distributions with those obtained via permuted distributions. Relatedness levels within sex were also compared in the Serranías del Burro.

A neighbor-joining (NJ) tree was developed using transformed relatedness values $(1-r)$ in MEGA (Kumar et al. 2001) to achieve a pictorial representation of relationships of adult and subadult bears in Big Bend NP, the Black Gap WMA, the Trans-Pecos region, and the Sierra del Carmen. Additionally, we assessed relationships among black bears in Big Bend NP via pedigree path analysis. We used data sources including $r$ values, previous mtDNA sequence data (Onorato et al. 2004), demographic and spatial data (Onorato et al. 2003), historical accounts (Onorato and Hellgren 2001), and additional microsatellite analyses to derive information necessary to complete the pedigree. All captured males that had a mtDNA haplotype different from those of adult fe- males were automatically omitted from the pedigree because it is highly unlikely that they descended from those females (Onorato et al. 2004).

\section{Results}

The number of alleles detected in the seven microsatellite loci ranged from four to six for the 32 bears sampled in Big Bend NP (Table 1). Levels of $H_{\mathrm{o}}$ were greater than levels of $H_{\mathrm{e}}$ for six of the seven loci. Mean PIC was 0.639, whereas the total exclusionary powers of the combined loci for the first and second parents were 0.907 and 0.987 , respectively.

We deciphered purported sires for cubs of the year using exclusion in three cases. Assessment of paternity via a likelihood-based approach was effective at resolving paternity for 7 of 12 cubs of the year with high levels $(\geq 80 \%)$ of statistical confidence (Table 2). Multiple paternity was estimated to have occurred in one litter. Paternity for four of the seven cubs was assigned to adult male BGWMA1, a bear that had been relocated to the Black Gap WMA.

Mean overall $r$ values within five populations of black bears encompassing the Mexico-Texas metapopulation ranged from 0.001 to 0.038 and approximated the expected value of 0 . The highest overall $r$ value for a population was in Big Bend NP. Relatedness $( \pm \mathrm{SD})$ values for known mother-offspring dyads in Big Bend NP averaged $0.480 \pm$ 0.078 , and father-offspring $r$ values derived via likelihoodbased or exclusion methods also approximated the expected value of $0.50(0.482 \pm 0.142$; Table 2$)$. Mean $r$ values for adult dyads within sex in Big Bend NP revealed that adult females $(N=6)$ were more related to each other (mean $r=$ $0.183 \pm 0.258)$ than adult males were to each other $(N=6$, $r=0.061 \pm 0.232)$, although this difference was not significant $(P=0.19)$. Average pairwise $r$ values for adult malefemale dyads $(0.056 \pm 0.180)$ depicted the low level of relatedness between animals of reproductive age. In the Burros population, a source population of Big Bend NP, there was also no difference $(P=0.22)$ in relatedness for male-male or female-female dyads (females, $N=24$, mean $r=0.084 \pm$ 0.227; males, $N=13, r=0.118 \pm 0.208$ ).

The NJ tree depicts a matriarchal structure in the Big Bend NP population (Fig. 2). All adult females in the Park except BIBE5 were allocated to the upper clade of the NJ tree. Furthermore, bears that could be classified as dispersing individuals or that were collected in other populations 
Table 2. Relatedness values ( $r$ ) for parent-offspring dyads of American black bears in Big Bend National Park deciphered via field observations or paternal likelihood calculations.

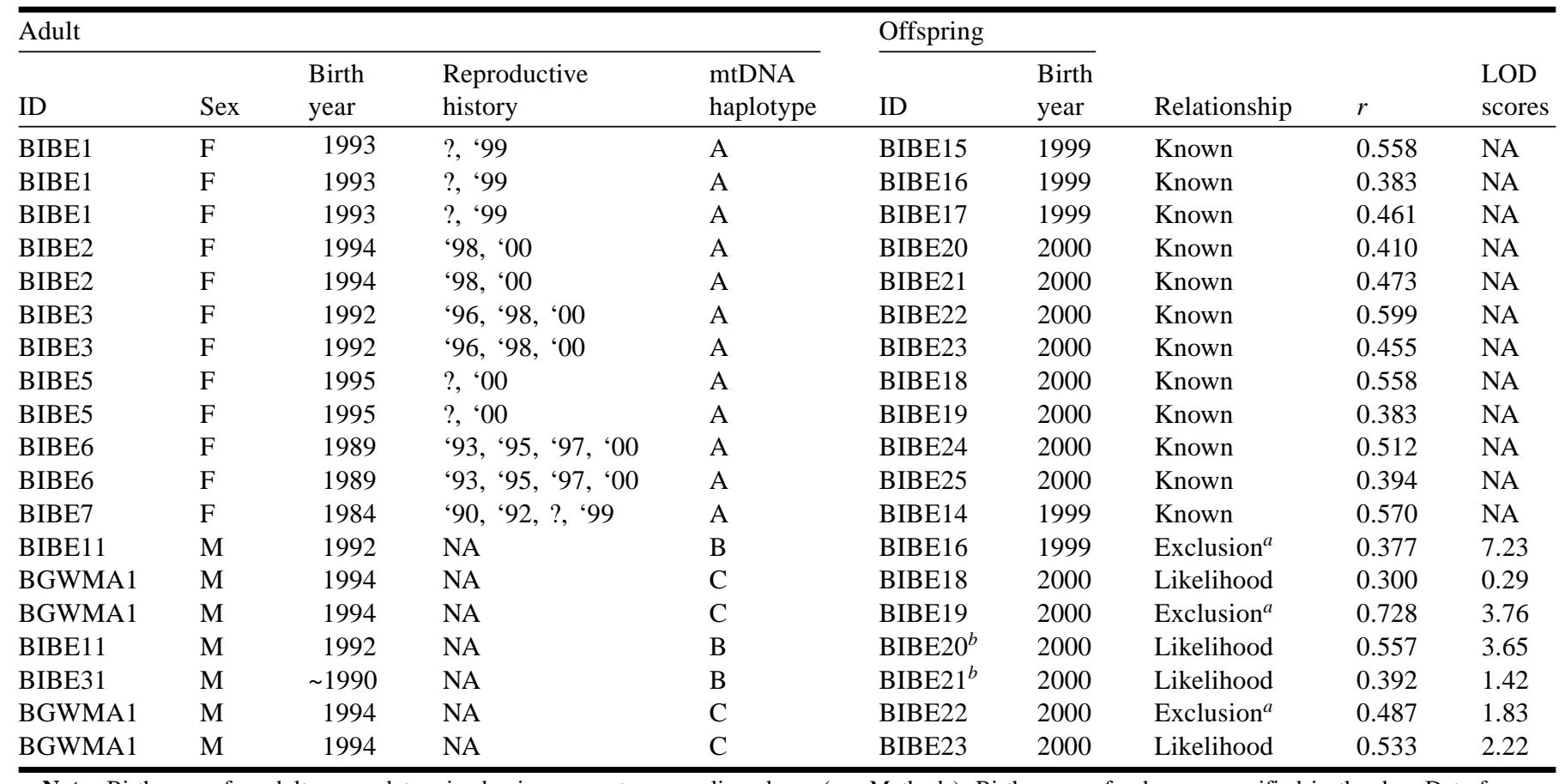

Note: Birth years for adults were determined using cementum annuli analyses (see Methods). Birth years of cubs were verified in the den. Data for mtDNA haplotypes were collected previously by the authors (Onorato et al. 2004). The LOD scores represent successful paternity assignments confirmed at a statistical confidence level of $\geq 80 \%$ using the program CERVUS. NA, not applicable.

${ }^{a}$ Father-cub relationships were successfully characterized via both exclusion and likelihood methods.

${ }^{b}$ Half-siblings that constitute a litter sired by two different fathers.

were congregated on the lower nodes of the tree. Thirteen of the 16 bears in this clade were males, and many represent a grouping of bears (Trans-Pecos and Black Gap WMA samples) that have dispersed into western Texas from Mexico.

Demographic and genetic data were used to reconstruct pedigree relationships for 23 (of 31) captured bears in the Park between 1998 and 2000 (Fig. 3). The five oldest females in Big Bend NP were highly related $(r=0.298$, Fig. 3). The oldest female, BIBE7, was related to BIBE2 $(r=0.251)$, BIBE3 $(r=0.281)$, and BIBE6 $(r=0.155)$ at levels that generally indicate half-sibling relatedness. The one adult female that appeared to be unrelated to some of the population was BIBE5, as indicated in the $\mathrm{NJ}$ tree (Fig. 2). This female was closely related to BIBE6 $(r=$ 0.335; Fig. 3) and BIBE27 ( $r=0.417)$, but unique alleles at two loci resulted in low levels of relatedness to other adult females. Nine male bears were not included in this pedigree owing to low levels of relatedness, exclusion of kinship connections determined via mtDNA haplotypes, or demographic data that did not correlate with reproductive cycles of adult females.

\section{Discussion}

Our results supported our initial prediction concerning similar levels of relatedness within Big Bend NP and a source population of bears in the Burros $(r=0.038$ and 0.037 , respectively). Similarly, our data supported the prediction of elevated levels of female relatedness in the Park resulting from female philopatry and the mtDNA haplotype common to all female bears in the Park (Onorato et al. 2004). Conversely, paternity assignments included a male from the nearby Black Gap WMA and did not include adult males that were closely related to reproductive females, thereby emphasizing the importance of male migration and dispersal between adjacent populations and the Park. Finally, pedigree analysis was consistent with the prediction that a single matriarch female recolonized the park during the mid-1980's.

Analyses restricted to samples collected in Big Bend NP (island population) and the Burros (mainland population; Doan-Crider 2003) demonstrated that these two populations exhibited similar levels of $H_{\mathrm{e}}$ (Big Bend $\mathrm{NP}=0.691$, Burros $=0.712$ ). Levels of microsatellite $H_{\mathrm{e}}$ for black bears in habitats considered insular (0.360 in Newfoundland, Paetkau and Strobeck 1994) or affected by low levels of gene flow (0.33 in White River National Wildlife Refuge, Warrillow et al. 2001) are much lower than those reported for Big Bend NP and other populations in the Mexico-Texas metapopulation (Onorato et al. 2003). Low levels of $H_{\mathrm{e}}$ do not necessarily indicate vulnerability of these populations to the effects of inbreeding depression because bear populations in Newfoundland are reported to number between 3000 and 10000 and the White River National Wildlife Refuge population is steadily increasing. Nevertheless, results for Big Bend NP are important from a conservation perspective. The levels of genetic variation in Big Bend NP are indicative of a population recharged by intermittent levels of gene flow from conspecifics in adjacent populations (Spong et al. 2000). Movement of bears between the Sierra del Carmen 
Fig. 2. Neighbor-joining tree computed using an adjusted relatedness $(1-r)$ index matrix for adult and subadult American black bears collected in Big Bend NP, Texas (BIBE), the Black Gap WMA (BGWMA), Sierra del Carmen (SDC), and Trans-Pecos region (TP). Groupings described in the text are represented by the solid, vertical lines.

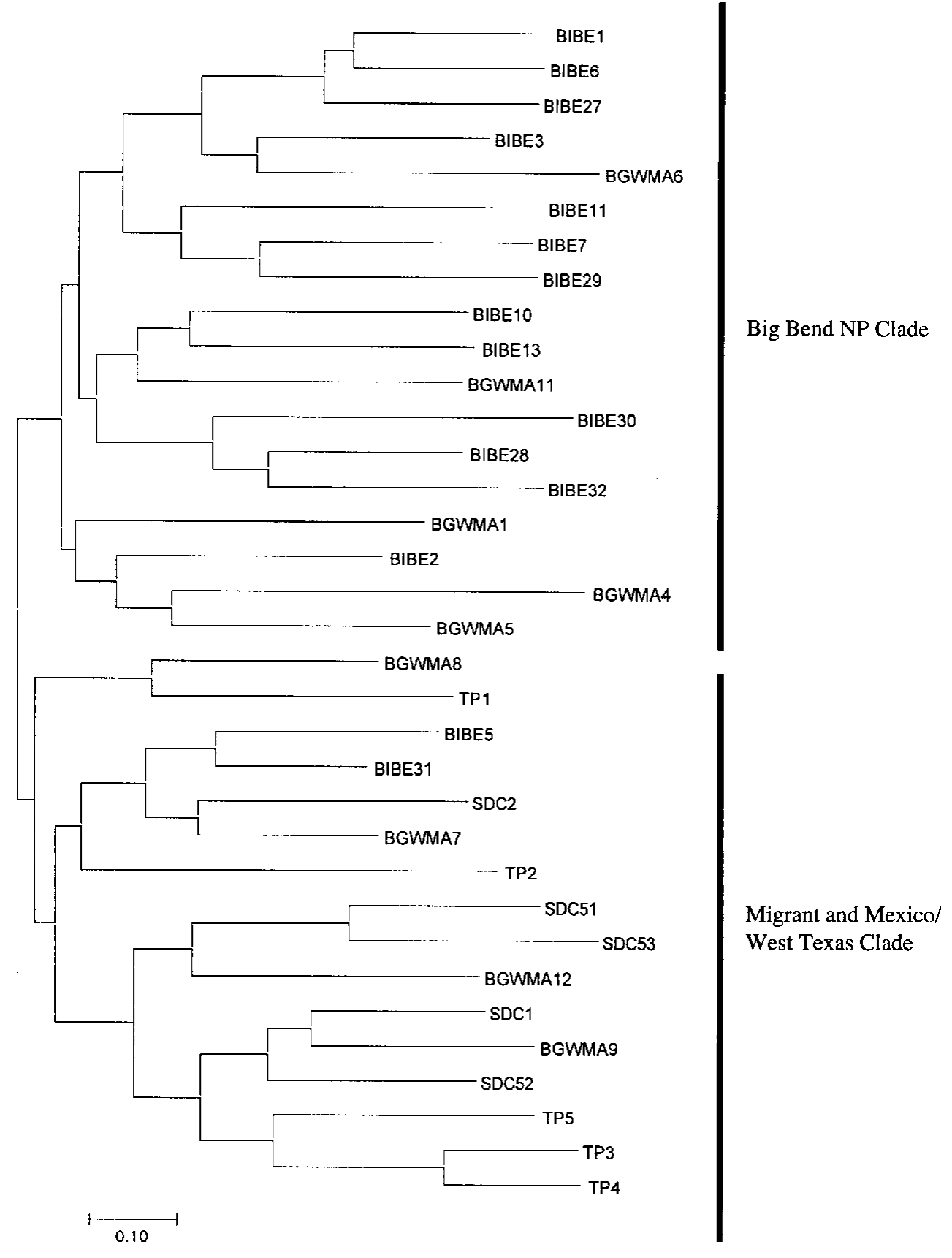

and Big Bend NP has been corroborated with field data (Onorato et al. 2003). Undoubtedly, the small population of black bears in Big Bend NP will be reliant on continued dispersal events from northern Mexico to maintain genetic variation.

Our paternity analyses indicated that one of five litters (20\%) that were completely censused in Big Bend NP (BIBE20-21) contained half-sibs sired by resident males. Multiple paternity in mammals is not unusual and has been noted in brown (Ursus arctos L., 1758) and black bears (Craighead et al. 1995; Schenk and Kovacs 1995), white- tailed deer (Odocoileus virginianus Zimmermann, 1780) (DeYoung et al. 2002), and pronghorn (Antilocapra americana Ord, 1815) (Carling et al. 2003). On the other hand, quantification of the prevalence of this behavior in the family Ursidae has rarely been reported. Craighead et al. (1995) described four cases of multiple paternity in Alaskan brown bears in 30 sampled litters $(13.3 \%)$.

The occurrence of multiple paternity in the small population of bears in Big Bend NP could be explained by the ecological and demographic characteristics of the population. Data collected during fieldwork from 1998 to 2000 demon- 
Fig. 3. Representation of the hypothesized pedigree for a majority of the population of American black bears in Big Bend National Park, Texas, between 1998 and 2000. Females are represented by octagons, males by squares. Larger shapes represent adult or subadult bears, and smaller shapes represent cubs of the year. Diamonds represent cubs of the year verified via field observations but not sampled. Dashed lines represent relationships inferred via relatedness among descendents of the hypothetical matriarch female. All other kinship connections (solid lines) were made via field observations. Numbers represent Big Bend NP animal IDs described in tables and the text. Year of birth for each animal is also noted. Relatedness values are assigned to relationships between adult females and offspring that were assessed via genetic analyses.

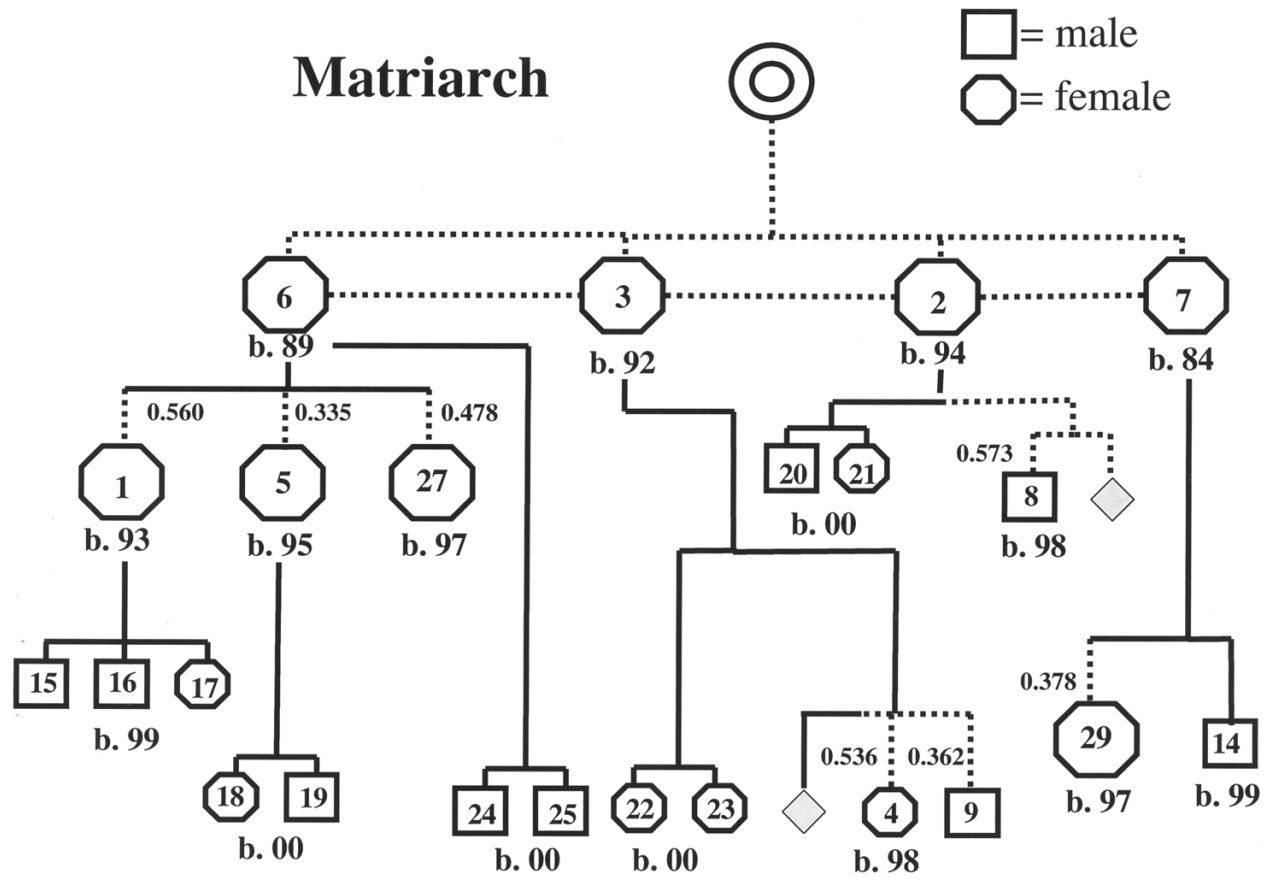

strated a large degree of overlap in home ranges of both male and female bears in the Chisos Mountains (Onorato et al. 2003). With only six known reproductive females active in the Park from 1998 to 2001 and approximately three or four resident adult male bears, the chances of promiscuity appear high. Roemer et al. (2001) found unexpectedly high levels of promiscuity within a population of island foxes (Urocyon littoralis Baird, 1857) on Santa Cruz Island, California. They attributed this behavior to the high density of the species on the island and the increased opportunities for extra-pair fertilizations that high density and home-range overlap provided. We estimated the density of black bears in Big Bend NP to be 23 bears $/ 100 \mathrm{~km}^{2}$ between 1998 and 2000 (Hellgren et al. 2005), which is in the midrange of black bear densities described across the United States (Garshelis 1994). However, the insular nature of bear habitat in the Chisos Mountains of Big Bend NP may increase the likelihood for intraspecific encounters and multiple fertilization of females.

Paternity assignment via exclusion was effective in this study in three cases. The reliability of exclusion probabilities can be affected by the presence of numerous close relatives in a system and by high levels of philopatry (Double et al. 1997). Our relatedness analyses demonstrated that a large portion of the small bear population in Big Bend NP is related, especially the adult females and cubs that composed over $50 \%$ of our sample. Additionally, we know that at least one adult male eluded capture during our trapping sessions. We believe that these were the primary reasons why the exclusion process was not more effective.
The population of bears in Big Bend NP maintained a level of relatedness that was similar to that of the large population in the Burros. The insular population in Big Bend NP would be expected to have higher levels of relatedness among bears, given that a majority of the population was composed of cubs and related adult females. We believe that a combination of migration of males from nearby populations (the Black Gap WMA and the Sierra del Carmen) and low levels of relatedness between adult females and resident males has resulted in relatedness levels in the Big Bend NP population that are similar to those of larger populations (e.g., the Burros). Although the overall relatedness levels for these populations are slightly greater than 0 , the values approximate the expected nil value for this statistic. The overall low levels of relatedness observed in the Trans-Pecos region, Black Gap WMA, and Sierra Del Carmen $(r=0.005$, 0.008 , and 0.001 , respectively) may be a result of small sample sizes, but Relatedness uses a correction factor to minimize this bias (Queller and Goodnight 1989). Low levels of $r$ in the Black Gap WMA and Trans-Pecos populations could be a result of the presence of numerous dispersing individuals (especially dispersing male bears from Mexico).

Quantification of relatedness within groups of mammals has been reported in several studies. Lucchini et al. (2002) reported high levels of relatedness $(r=0.252$ and 0.498$)$ in two recolonizing wolf packs in the western Italian Alps. This level of relatedness would be expected in a highly social mammal such as the wolf, which typically roams in a pack with a large proportion of related individuals. Cronin et al. (1999) reported $r$ values for brown bears in three popula- 
tions located in northern Alaska ( -0.0002 to -0.0019$)$. Negative $r$ values indicate low levels of relatedness within these Alaska populations, but reported standard deviations were high and suggested the presence of both related and unrelated bears in this region. Black bears in the Mexico-Texas metapopulation maintain slightly higher levels of relatedness, although $r$ values were not indicative of highly intrarelated populations. The lower level of relatedness in northern Alaska brown bears was probably caused by a variety of factors, including larger populations, greater dispersal distances, and contiguous habitat.

The trend towards higher levels of relatedness in femalefemale pairs compared with male-male dyads in Big Bend $\mathrm{NP}$ was indicative of a species that exhibits male-biased dispersal patterns. Additional evidence was provided by the neighbor-joining tree, which led us to conclude that the populations of bears in this portion of the Mexico-Texas metapopulation constitute two groups: a Big Bend NP clade composed mainly of adult and subadult bears from the Park, and migrant (Trans-Pecos) or resident bears from other populations (Black Gap WMA and Sierra del Carmen). Using a similar technique, Lucchini et al. (2002) demonstrated the presence of two separate groups of wolves recolonizing portions of the western Alps in Italy. Subadult (1-3 year old) male black bears typically disperse from their mother's natal range in search of a new home range (LeCount et al. 1984; Rogers 1987a, 1987b; Schwartz and Franzmann 1992; Smith and Clark 1994). The Park provides only a limited amount of suitable habitat (ca. $100 \mathrm{~km}^{2}$ ), resulting in dispersal of male bears from Big Bend NP north to mountain ranges (Glass, Davis, or Del Norte mountains) and south or east into Mexico. We verified the movement of subadult and yearling males from Big Bend NP into northern Mexico via field observations (Onorato et al. 2003, Hellgren et al. 2005). Male dispersal from the Sierra del Carmen to western Texas probably occurs regularly and supplements genetic variation in the semi-isolated population in Big Bend NP. Our paternity assignments assessed via likelihood give additional credence to this idea because of the paternal connection noted between several cubs in Big Bend NP and an adult male residing in the Black Gap WMA.

Mother-offspring relatedness (0.480) in Big Bend NP was in accordance with that recorded in larger, more established bear populations and approximated the expected value (0.5) for this relationship. Cronin et al. (1999) assessed motheroffspring relationships for brown bears in the Prudhoe Bay Region of Alaska and found that $r$ values for this relationship averaged 0.495 for 11 different litters. Similar levels of relatedness were noted for mother-offspring dyads in polar bears, Ursus maritimus Phipps, 1774 (mean $r=0.542, N=$ 6, Lunn et al. 2000). Relatedness of father-offspring dyads was also at the expected level for this relationship. The elevated variance observed in the father-offspring relatedness values was also present in the study by Cronin et al. (1999). We believe this is a result of the smaller number of pairwise relatedness values $(N=7)$ included in our father-offspring analysis compared with the mother-offspring analysis $(N=$ 12).

Our pedigree accounted for $72 \%$ of the 31 bears collected in Big Bend NP and portrayed a view of kinship infrequently documented in large carnivore populations
(Craighead et al. 1995; Cronin et al. 1999). The pedigree was mainly supported by known mother-offspring connections and supplemented by high relatedness values among adult females. Our pedigree analysis supports our prediction that a matriarch female recolonized the Chisos Mountains of Big Bend NP during the mid-1980's by dispersing from the mountains of northern Coahuila. We propose a scenario in which this female crossed the expanse of Chihuahuan Desert between the Sierra del Carmen and Big Bend NP, ultimately choosing to den in the Park (Onorato and Hellgren 2001). We postulate that two females (BIBE6 and BIBE3) are direct offspring of this matriarch, based on their ages and level of relatedness ( $r=0.429$; indicative of full-siblings). The first verified reproduction in Big Bend NP occurred in 1989, when a Park visitor photographed a female with cubs of the year (Skiles 1995). This year was also the birth year of BIBE6. Other evidence consistent with philopatry and the matriarchal scenario is that all females captured in the Park contain mtDNA haplotype A, which dominated in the Park population during the study period but was far less common in northern Mexico (Onorato et al. 2004). Although BIBE7 was old enough to serve as the hypothetical matriarch, her genetic data did not support this contention. We believe that the original matriarch female was not captured and that she either died or returned to Mexico.

The population of black bears in Big Bend NP will be reliant on periodic gene flow via male bears dispersing from ranges in northern Coahuila to persist, maintain genetic diversity, and remain devoid of problems associated with inbreeding. Infrequent but verified movement of females between populations in the Mexico-Texas metapopulation will also maintain genetic diversity in the insular Park population (Hellgren et al. 2005). These two factors highlight the importance of undisturbed dispersal links between Coahuila and available habitat in western Texas for continued recolonization of bears along the international border.

\section{Acknowledgments}

We thank B.R. McKinney (Texas Parks and Wildlife Department and CEMEX Inc.), C. Costello (Hornocker Wildlife Institute), and D.L. Doan-Crider for contributing samples for genetic analyses. Additional thanks go to F.S. Mitchell, S. Ginger, P. Luce, M. Kasparian, M. Criffield, C. Tredick, G. Vose, N. Herring, numerous Big Bend NP employees and field volunteers, and R.A. Van Den Bussche's laboratory staff for their assistance in making the collection of these data feasible. This study was supported by funding from the Natural Resource Preservation Program (through the US Geological Survey, US Department of the Interior National Park Service, and Big Bend National Park). We thank D.M. Leslie, Jr., and the Oklahoma Cooperative Fish and Wildlife Research Unit (US Geological Survey, Biological Resources Division, Oklahoma State University, Oklahoma Department of Wildlife Conservation, and Wildlife Management Institute, cooperating) for administrative and logistic support. We acknowledge additional funding granted by the Wyoming Chapter of the Wildlife Society (Memorial Bear Grant), the American Museum of Natural History (Theodore Roosevelt Memorial Fund), and the Robert L. Lochmiller II Endowed Scholarship. 


\section{References}

Banks, S.C., Skerratt, L.F., and Taylor, A.C. 2002. Female dispersal and relatedness structure in common wombats (Vombatus ursinus). J. Zool. (Lond.), 256: 389-399.

Blouin, M.S., Parsons, M., Lacaille, V., and Lotz, S. 1996. Use of microsatellite loci to classify individuals by relatedness. Mol. Ecol. 5: 393-401.

Carling, M.D., Wiseman, P.A., and Byers, J.A. 2003. Microsatellite analysis reveals multiple paternity in a population of wild pronghorn antelopes (Antilocapra americana). J. Mammal. 84: 1237-1243.

Clapham, P.J., and Palsboll, P.J. 1997. Molecular analysis of paternity shows promiscuous mating in female humpback whales (Megaptera novaengliae, Borowski). Proc. R. Soc. Lond. B Biol. Sci. 264: 95-98.

Constable, J.L., Ashley, M.V., Goodall, J., and Pusey, A.E. 2001. Noninvasive paternity assignment in Gombe chimpanzees. Mol. Ecol. 10: 1279-1300.

Craighead, L., Paetkau, D., Reynolds, H.V., Vyse, E.R., and Strobeck, C. 1995. Microsatellite analysis of paternity and reproduction in Arctic grizzly bears. J. Hered. 86: 255-261.

Cronin, M., Shideler, R., Hechtel, J., Strobeck, C., and Paetkau, D. 1999. Genetic relationships of grizzly bears (Ursus arctos) in the Prudhoe Bay region of Alaska: inference from microsatellite DNA, mitochondrial DNA, and field observations. J. Hered. 90: 622-628.

DeYoung, R.W., Demarais, S., Gonzales, R.A., Honeycutt, R.L., and Gee, K.L. 2002. Multiple paternity in white-tailed deer (Odocoileus virginianus) revealed by DNA microsatellites. J. Mammal. 83: 884-892.

Doan-Crider, D.L. 2003. Movements and spatiotemporal variation in relation to food productivity and distribution, and population dynamics of the Mexican black bear in the Serranías del Burro, Coahuila, Mexico. Ph.D. thesis, Texas A\&M UniversityKingsville, Kingsville, Tex.

Double, M., Cockburn, A., Barry, S., and Smouse, P. 1997. Exclusion probabilities for single-locus paternity analysis when related males compete for matings. Mol. Ecol. 6: 1155-1166.

Engh, A.L., Esch, K., Smale, L., and Holekamp, K.E. 2000. Mechanisms of maternal rank 'inheritance' in the spotted hyaena, Crocuta crocuta. Anim. Behav. 60: 323-332.

Garshelis, D.L. 1994. Density-dependent population regulation of black bears. In Density-dependent population regulation of black, brown and polar bears. Edited by M. Taylor. International Association for Bear Research and Management, Missoula, Mont. pp. 3-14.

Girman, D.J., Mills, M.G.L., Geffen, E., and Wayne, R.K. 1997. A molecular genetic analysis of social structure, dispersal, and interpack relationships of the African wild dog (Lycaon pictus). Behav. Ecol. Sociobiol. 40: 187-198.

Gompper, M.E., Gittleman, J.L., and Wayne, R.K. 1998. Dispersal, philopatry, and genetic relatedness in a social carnivore: comparing males and females. Mol. Ecol. 7: 157-163.

Guo, S.W., and Thompson, E.A. 1992. Performing the exact test of Hardy-Weinberg proportion for multiple alleles. Biometrics, 48: 361-372.

Hellgren, E.C., Onorato, D.P., and Skiles, J.R. 2005. Dynamics of a black bear population within a desert metapopulation. Biol. Conserv. 122: 131-140.

Kays, R.W., Gittleman, J.L., and Wayne, R.K. 2000. Microsatellite analysis of kinkajou social organization. Mol. Ecol. 9: 743-751.

Kumar, S., Tamura, K., Jakobsen, I.B., and Nei, M. 2001. MEGA2: molecular evolutionary genetics analysis software. Bioinformatics, 17: 1244-1245.

LeCount, A.L., Smith, R.H., and Wegge, J.R. 1984. Black bear habitat requirements in central Arizona. Report No. 14, Arizona Game and Fish Department, Phoenix, Ariz.

Lucchini, V., Fabbri, E., Marucco, F., Ricci, S., Boitani, L., and Randi, E. 2002. Noninvasive molecular tracking of colonizing wolf (Canis lupus) packs in the western Italian Alps. Mol. Ecol. 11: $857-868$.

Lunn, N.J., Paetkau, D., Calvert, W., Atkinson, S., Taylor, M., and Strobeck, C. 2000. Cub adoption by polar bears (Ursus maritimus): determining relatedness with microsatellite markers. J. Zool. (Lond.), 251: 23-30.

Maniatis, F., Fritsch, E.F., and Sambrook, J. 1989. Molecular cloning: a laboratory manual. Cold Spring Harbor Laboratory Press, Cold Spring Harbor, N.Y.

Marshall, T.C., Slate, J., Kruuk, L.E.B., and Pemberton, J.M. 1998. Statistical confidence for likelihood-based paternity inference in natural populations. Mol. Ecol. 7: 639-655.

McKinney, B.R., and Pittman, M.T. 2000. Habitat, diet, home range, and seasonal movement of resident and relocated black bears in west Texas. Project WER57-STATE, Texas Parks and Wildlife Department, Austin, Tex.

McLellan, B., and Hovey, F. 2001. Natal dispersal of grizzly bears. Can. J. Zool. 79: 838-844.

Onorato, D.P., and Hellgren, E.C. 2001. Black bear at the border: the recolonization of the Trans-Pecos. In Large mammal restoration: ecological and sociological challenges in the 21 st century. Edited by D.S. Maehr, R.F. Noss, and J.L. Larkin. Island Press, Washington, D.C. pp. 245-259.

Onorato, D.P., Hellgren, E.C., Mitchell, F.S., and Skiles, R., Jr. 2003. Home range and habitat use of American black bears on a desert montane island in Texas. Ursus, 14: 120-129.

Onorato, D.P., Hellgren, E.C., Van Den Bussche, R.A., and DoanCrider, D.L. 2004. Phylogeographic patterns within a metapopulation of black bears (Ursus americanus) in the American Southwest. J. Mammal. 85: 160-167.

Ostrander, E.A., Sprague, G.F., and Rine, J. 1993. Identification and characterization of dinucleotide repeat $(\mathrm{CA})_{\mathrm{n}}$ markers for genetic mapping in dog. Genomics, 16: 207-213.

Packer, C., Gilbert, D.A., Pusey, A.E., and O'Brien, S.J. 1991. A molecular genetic analysis of kinship and cooperation in African lions. Nature (Lond.), 351: 562-565.

Paetkau, D., and Strobeck, C. 1994. Microsatellite analysis of genetic variation in black bear populations. Mol. Ecol. 3: 489-495.

Paetkau, D., Calvert, W., Stirling, I., and Strobeck, C. 1995. Microsatellite analysis of population structure in Canadian polar bears. Mol. Ecol. 4: 347-354.

Paetkau, D., Shields, G.F., and Strobeck, C. 1998. Gene flow between insular, coastal and interior populations of brown bears in Alaska. Mol. Ecol. 7: 1283-1292.

Pelton, M.R., Coley, A.B., Eason, T.H., Doan Martinez, D.L., Pederson, J.A., van Manen, F.T., and Weaver, K.M. 1999. American black bear conservation action plan. In Bears: status survey and conservation action plan. Edited by C. Servheen, S. Herrero, and B. Peyton. IUCN/SSC Bear Specialist Group, Gland, Switzerland. pp. 144-156.

Queller, D.C., and Goodnight, K.F. 1989. Estimating relatedness using genetic markers. Evolution, 43: 258-275.

Rannala, B., and Mountain, J.L. 1997. Detecting immigration by using multilocus genotypes. Proc. Natl. Acad. Sci. U.S.A. 94: 9197-9201.

Roemer, G.W., Smith, D.A., Garcelon, D.K., and Wayne, R.K. 
2001. The behavioural ecology of the island fox (Urocyon littoralis). J. Zool. (Lond.), 255: 1-14.

Rogers, L.L. 1987a. Effects of food supply and kinship on social behavior, movements, and population growth of black bears in northeastern Minnesota. Wildl. Monogr. No. 97.

Rogers, L.L. 1987b. Factors influencing dispersal in the black bear. In Mammalian dispersal patterns. Edited by B.D. Chepko-Sade and Z.T. Halpin. University of Chicago Press, Chicago. pp. 7584.

Schaller, G.B. 1972. The Serengeti lion; a study of predator-prey relations. University of Chicago Press, Chicago.

Schenk, A., and Kovacs, K.M. 1995. Multiple mating between black bears revealed by DNA fingerprinting. Anim. Behav. 50: $1483-1490$.

Schenk, A., Obbard, M.E., and Kovacs, K.M. 1998. Genetic relatedness and home-range overlap among female black bears (Ursus americanus) in northern Ontario, Canada. Can. J. Zool. 76(8): 1511-1519.

Schwartz, C.C., and Franzmann, A.W. 1992. Dispersal and survival of subadult black bears from the Kenai Peninsula, Alaska. J. Wildl. Manag. 56: 426-431.

Skiles, J.R. 1995. Black bears in Big Bend National Park - the Tex-Mex connection. In Proceedings of the 5th Western Black Bear Workshop: Human - Black Bear Interactions, Provo, Utah,
22-25 February 1994. Edited by J. Auger and H.L. Black. Brigham Young University Press, Provo, Utah. pp. 67-73.

Smith, K.G., and Clark, J.D. 1994. Black bears in Arkansas characteristics of a successful translocation. J. Mammal. 75: 309-320.

Sokal, R.R., and Rohlf, F.J. 1995. Biometry. 3rd ed. W.H. Freeman and Company, New York.

Spong, G., Johansson, M., and Bjorklund, M. 2000. High genetic variation in leopards indicates large and long-term stable effective population size. Mol. Ecol. 9: 1773-1782.

Waits, L., Taberlet, P., Swenson, J.E., Sandegren, F., and Franzen, R. 2000. Nuclear DNA microsatellite analysis of genetic diversity and gene flow in the Scandinavian brown bear (Ursus arctos). Mol. Ecol. 9: 421-431.

Warrillow, J., Culver, M., Hallerman, E., and Vaughan, M. 2001. Subspecific affinity of black bears in the White River National Wildlife Refuge. J. Hered. 92: 226-233.

White, T.H., Bowman, J.L., Leopold, B.D., Jacobson, H.A., Smith, W.P., and Vilella, F.J. 2000. Influence of Mississippi alluvial valley rivers on black bear movements and dispersal: implications for Louisiana black bear recovery. Biol. Conserv. 95: 323331.

Willey, C.H. 1974. Aging black bears from first premolar tooth sections. J. Wildl. Manag. 38: 97-100. 